\title{
Clinical Study Committee Financial Disclosure Form
}

National Cancer Institute

\section{Source}

National Cancer Institute. Clinical Study Committee Financial Disclosure Form. NCI

Thesaurus. Code C125422.

A legal document completed by clinical trial independent committee members disclosing any financial arrangement between the member and the sponsor(s) of a clinical study. 